\title{
NUMERICAL ANALYSIS OF STRESS AND STRAIN OCCURRING IN THE CONTACT AREA OF CERAMIC HEAD - CERAMIC CUP IN THE HIP ENDOPROSTHESES
}

\author{
Michat Sobociński \\ Institute of Mechanical Technology, Czestochowa University of Technology \\ Częstochowa, Poland \\ sobocinski@iop.pcz.pl
}

\begin{abstract}
The paper presents the results of numerical analysis of the system "ceramic head - ceramic cup" in the hip joint endoprosthesis. Applying the $\mathrm{Al}_{2} \mathrm{O}_{3}$ ceramics in this kind of solutions, apart from all values of this material, can lead to grinding, if a high load is used. The analysis was run on the ADINA system. The geometrical model was elaborated on real measurements of the elements of endoprosthesis and also on the results provided by the producer.
\end{abstract}

Keywords: endoprosthesis of hip joint, numerical modeling stress, strain Weibull's model

\section{Probability of grinding of the ceramic element of the hip joint endoprosthesis}

Cooperation between the elements of the system "head - cup" is particularly important due to a complex kind of strain and displacement that occurs in an artificial hip joint. It is important not only because of cooperation elements, but also for other parts and elements of the endoprosthesis and tissues surrounding the implant. Particularly important is the influence of the stress range on possibilities of i.e. breaking or loosening the pivot or even the cup damage.

It is very common to exchange any damaged or used elements. Those are modular endoprostheses. Among all cup parts there are as follows:

- Metal cover fixed with bone cement

- Metal cover fixed without bone cement

- Metal cover fixed without bone cement stabilized with bolts

- Metal cover fixed with sharp-shaped screw

- Fixing technic ,press fit" [1].

The complexity of the processes that take place requires one to closely analyze the stress and strain in all applied solutions. The ceramics used in them exhibit quite a slight plastic deformation before it grinds, which takes place due to a various distribution of cracks. If compared to metal, the defects of which might be higher, without injury of the material features, the ceramics exhibit defects decreas- 
ing its durability that range from 5 to $200 \mu \mathrm{m}$. They are extremely small to locate and eliminate. To define the range of values of ceramic strength at one-axis stress, the Weibull's statistic theory is used based on the assumptions:

- the material is homogeneous,

- the number of defects decreasing the strength of the material is the same in each part of ceramic element,

- the distribution of defects is stochastic,

- the defects's sizes are comparatively small to the sizes of elements.

According to Weibull's model each element has its own strength connected with all particular elements of volume or surface. The probability of failure $P_{f}$ is defined by the correlation:

$$
P_{f}=1-\exp \left(-\int_{V}\left(\frac{\sigma-\sigma_{u}}{\sigma_{0}}\right)^{m} d V\right)
$$

where:

$\sigma$ - crushing stress,

$\sigma_{u}$ - equal stress $\sigma$, for which $P_{f}=0$, where sometimes $\sigma_{u}=0$,

$\sigma_{0}$ - specific crushing stress for $P_{f}=63,2 \%$,

$m$ - Weibull's module [2].

The Weibull's module $m$ defines the degree of the material strength range and is connected with probability of the defects. The higher value $m$ - the lower strength distribution what decreases the chance of injury. Figure 1 illustrates the interaction between both parameters $m$ and $\sigma_{0}$ and the probability of grinding $P_{f}$ as the function of bending crush stress [3].

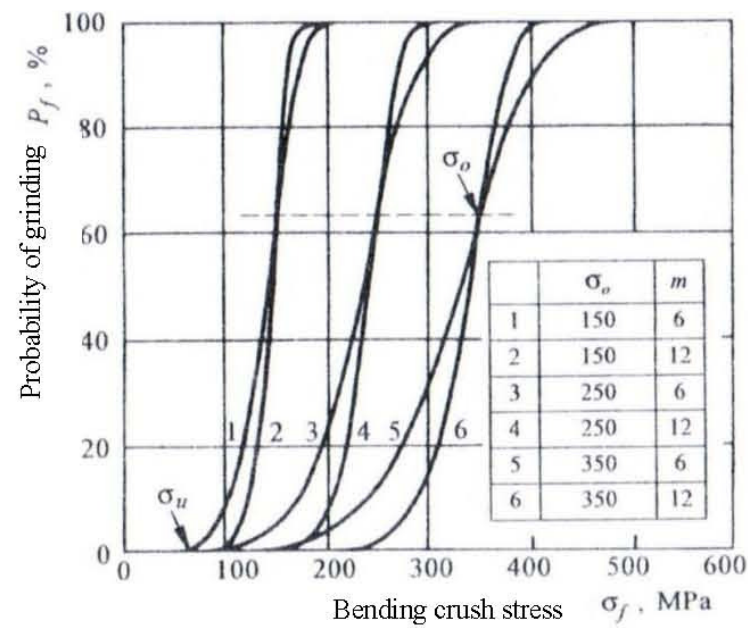

Fig. 1. The influence of Weibull's parameters $m$ and $\sigma_{0}$ on probability of crush $P_{f}$ as function of bending crush stress $\sigma_{f}$ [3] 


\section{The numerical analysis of stress and strain in the system "head - cup" in the hip joint endoprosthesis where ceramics elements are used}

Figure 2 presents the solution called Plasmacup SC by Aesculap accepted for calculations.

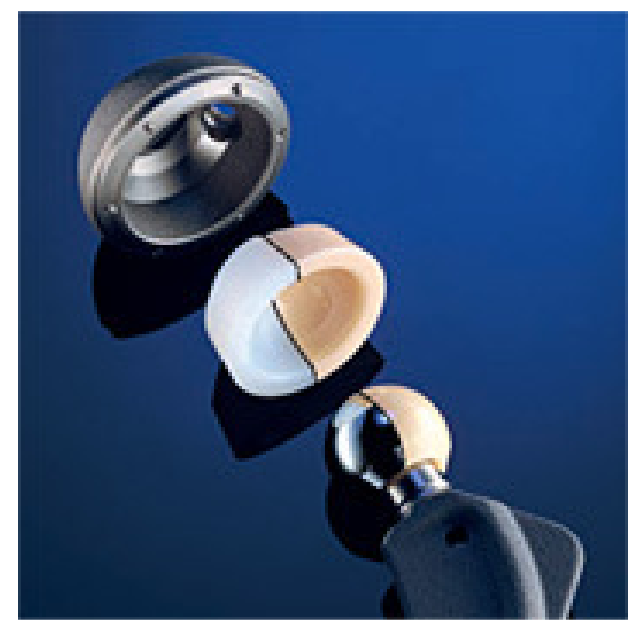

Fig. 2. The system of cups Plasmacup S.C. (physical model) [4]

The numerical analysis was conducted on the ADINA program. The geometrical model was elaborated on values of the real cups and heads provided by the producer [4]. The spherical model was built directly in the ADINA.

The view of all elements of the numerical model presents the Figure 3, and the load model is shown in Figure 4.

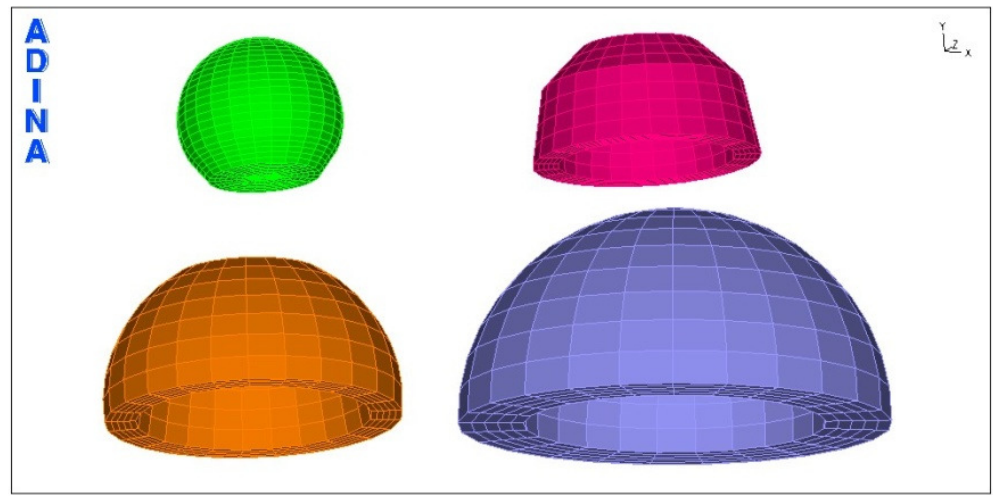

Fig. 3. Geometrical model of the accepted solution 


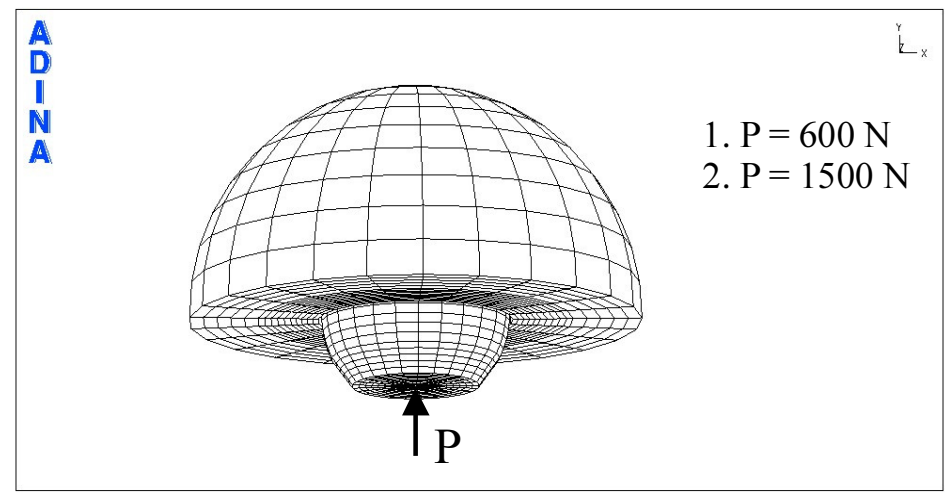

Fig. 4. The model of load in the analyzed system

To build the model of a 3D Solid type [5], the discreet model was constructed of the following cubic elements:

- head - 6250 elements,

- cup - 1250 elements,

- cup cover - 1250 elements,

- bone tissue surrounding the implant - 1250 elements, fixed on 10292 nodes.

Strength parameters of the materials and bone tissue used in analysis are presented in Table 1.

Table 1

Mechanical features of biomaterials and bone tissue [6]

\begin{tabular}{|c|c|c|}
\hline Element of the model & Young's module [MPa] & Poisson's coefficient $v$ \\
\hline Core bone & $1.7 \times 10^{4}$ & 0.35 \\
\hline Alloy Ti6Al4V & $1.1 \times 10^{5}$ & 0.3 \\
\hline Ceramics $\mathrm{Al}_{2} \mathrm{O}_{3}$ & $3.8 \times 10^{5}$ & 0.22 \\
\hline
\end{tabular}

In order to make the system stabile, the model was rigidly fixed on an external facet reflecting the external part of bone tissue surrounding the implant.

The discreet model of the system "head - cup" was elaborated on the elements made of ceramics.

Figures 5-8 illustrate the obtained results of stress and strain in the analyzed system "ceramic head - ceramic cup", with the load 600 and $1500 \mathrm{~N}$ respectively, and cross-section XY for separate elements.

Figure 9 presents the obtained maximum values of the stress for each element of the system with the load strength 600 and $1500 \mathrm{~N}$, respectively.

Figure 10 presents the maximum values of strain for each element also with the load 600 and $1500 \mathrm{~N}$, respectively. 


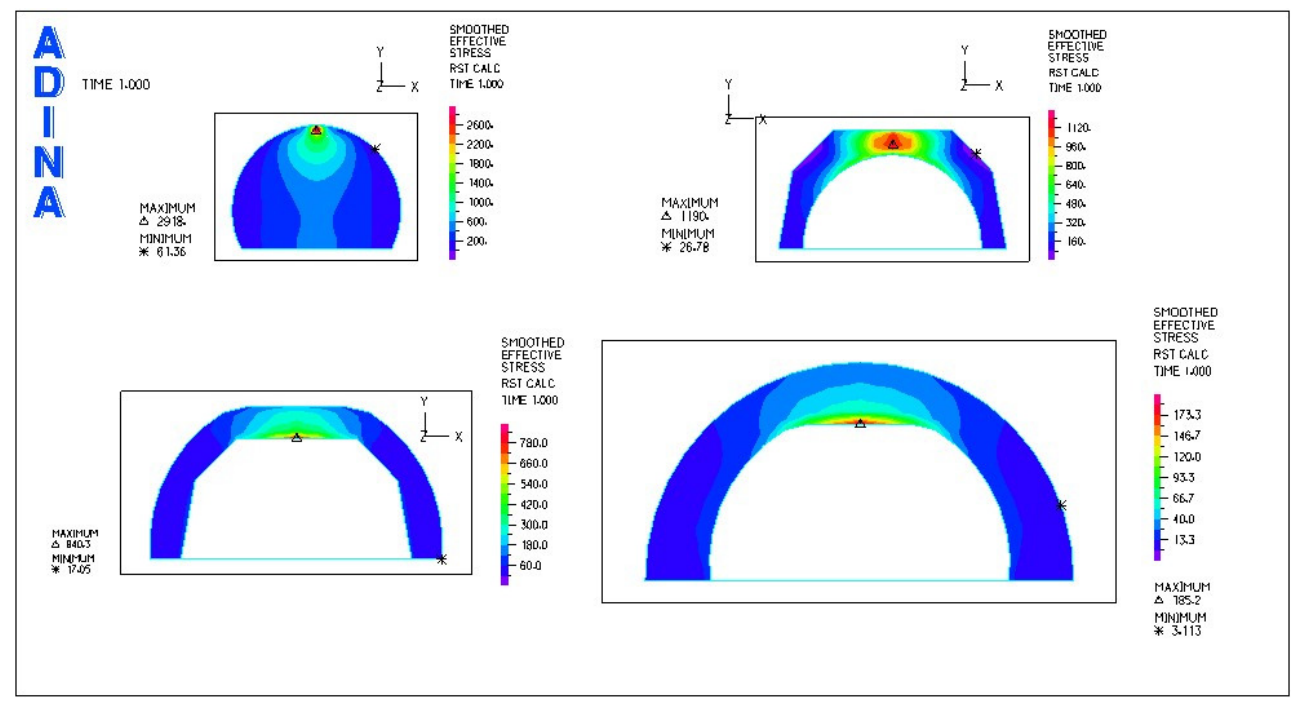

Fig. 5. Stress patterns $\sigma_{z r}[\mathrm{MPa}]$ in cross-section of each element of the analyzed system "ceramic head - ceramic cup", with the load $600 \mathrm{~N}$

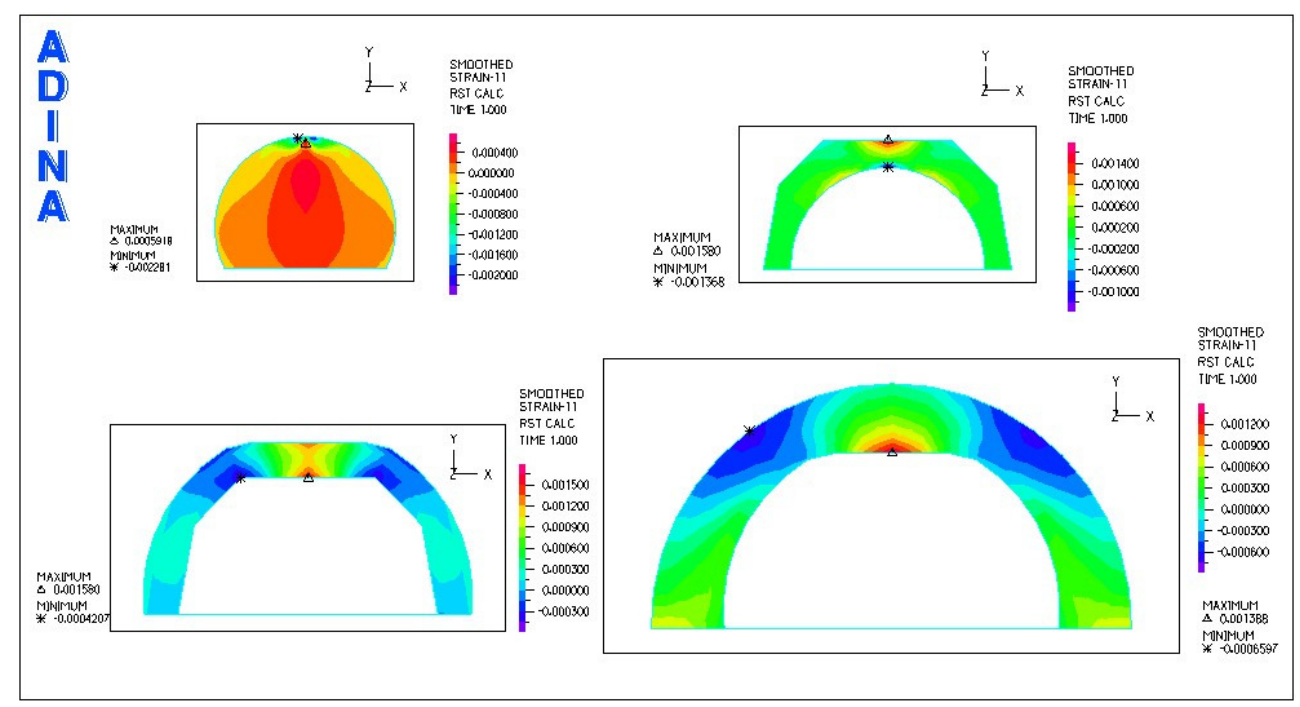

Fig. 6. Strain patterns in cross-section for each element of the analyzed system "ceramic head - ceramic cup" with the load $600 \mathrm{~N}$ 


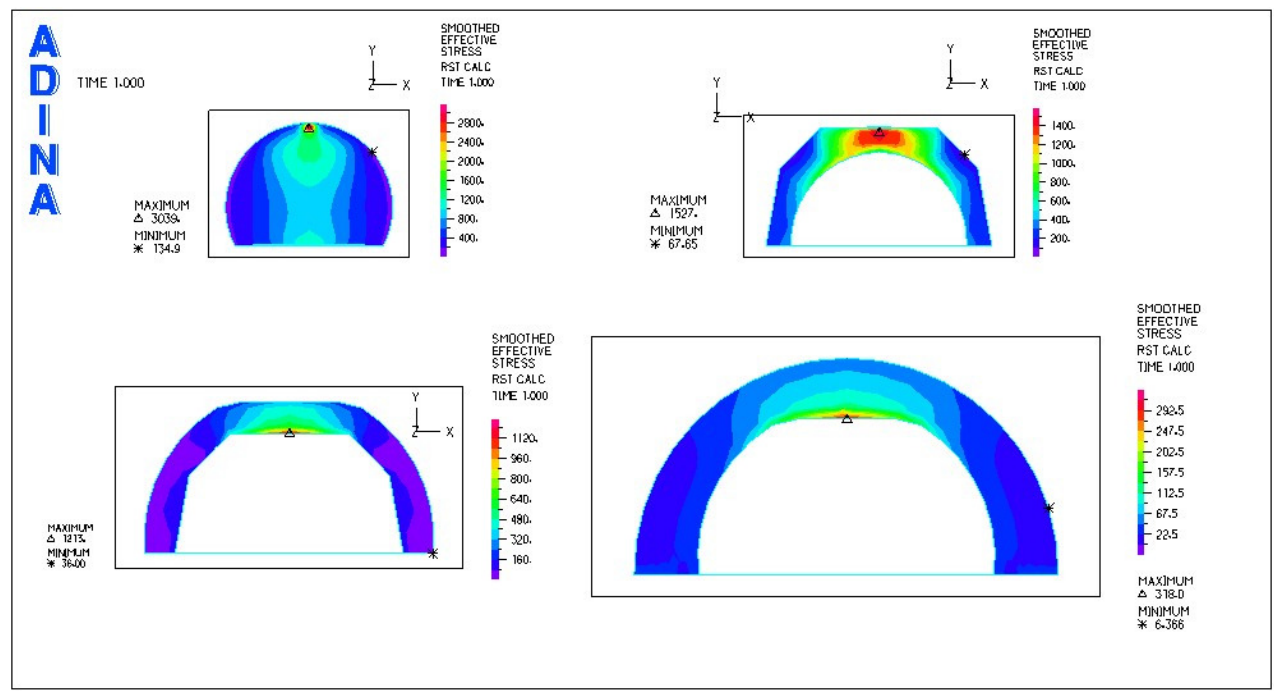

Fig. 7. Stress pattern $\sigma_{z r}[\mathrm{MPa}]$ in cross-section of each element of the analyzed system "ceramic head - ceramic cup", with the load $1500 \mathrm{~N}$

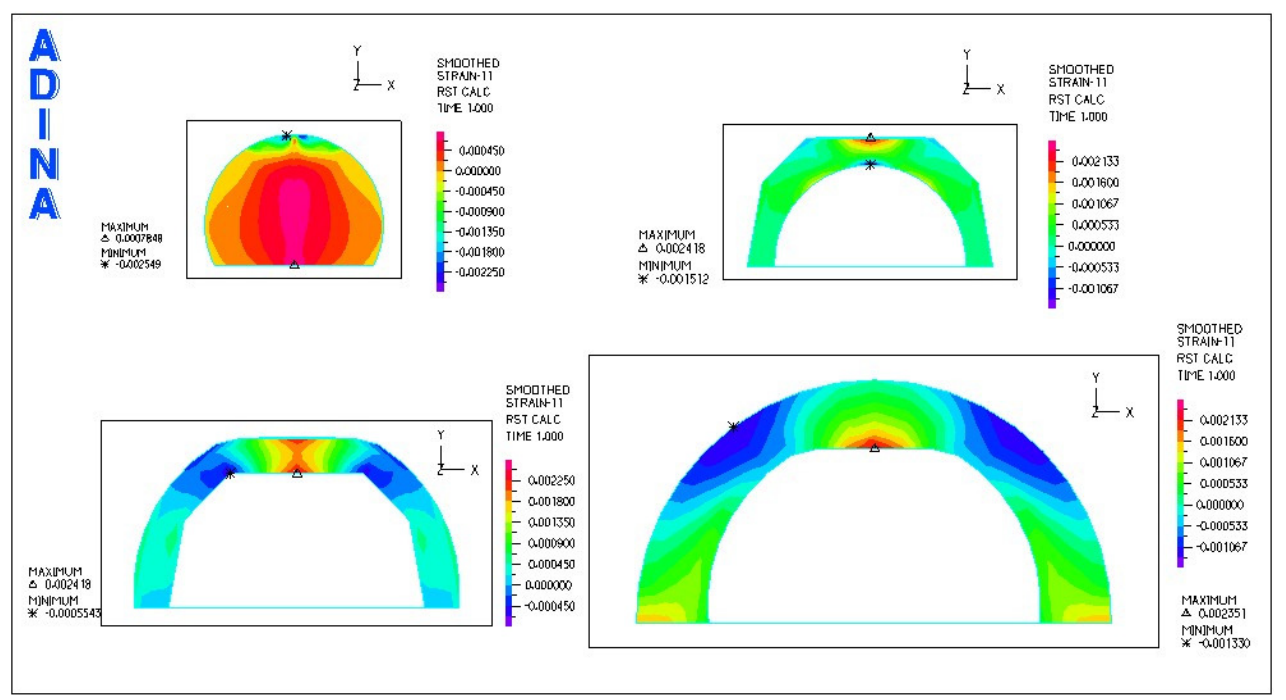

Fig. 8. Strain patterns in cross-section for each element of the analyzed system "ceramic head - ceramic cup" with the load $1500 \mathrm{~N}$ 


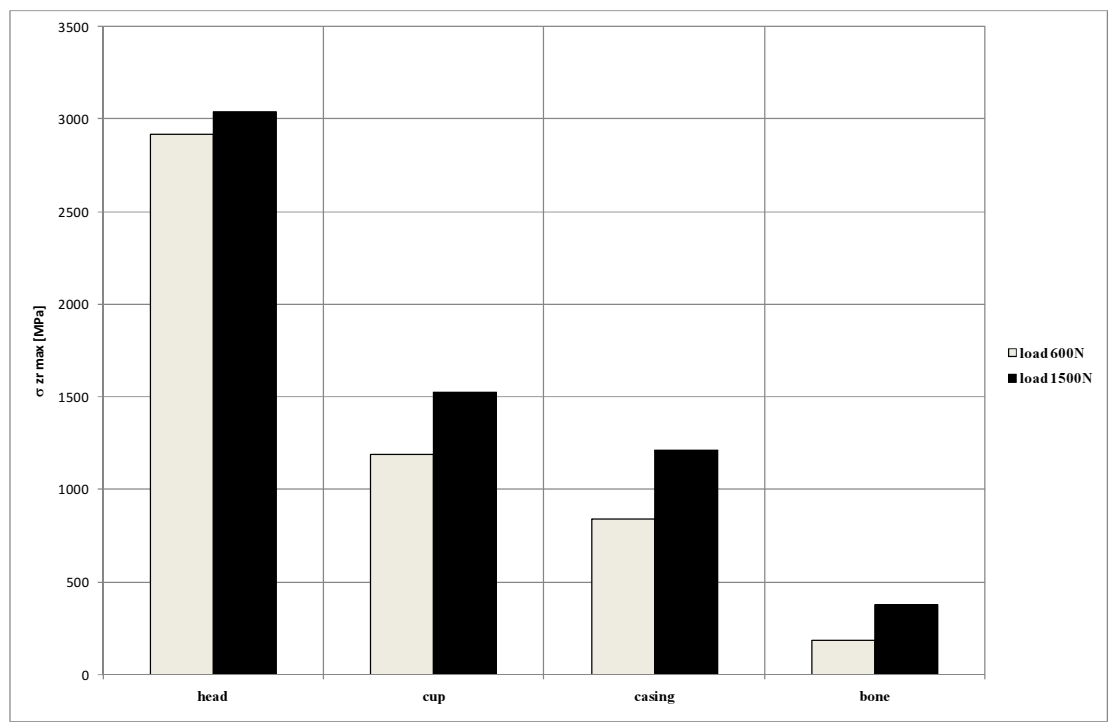

Fig. 9. Maximum values of the stress in the analyzed system "ceramic head - ceramic cup" with the loads 600 and $1500 \mathrm{~N}$

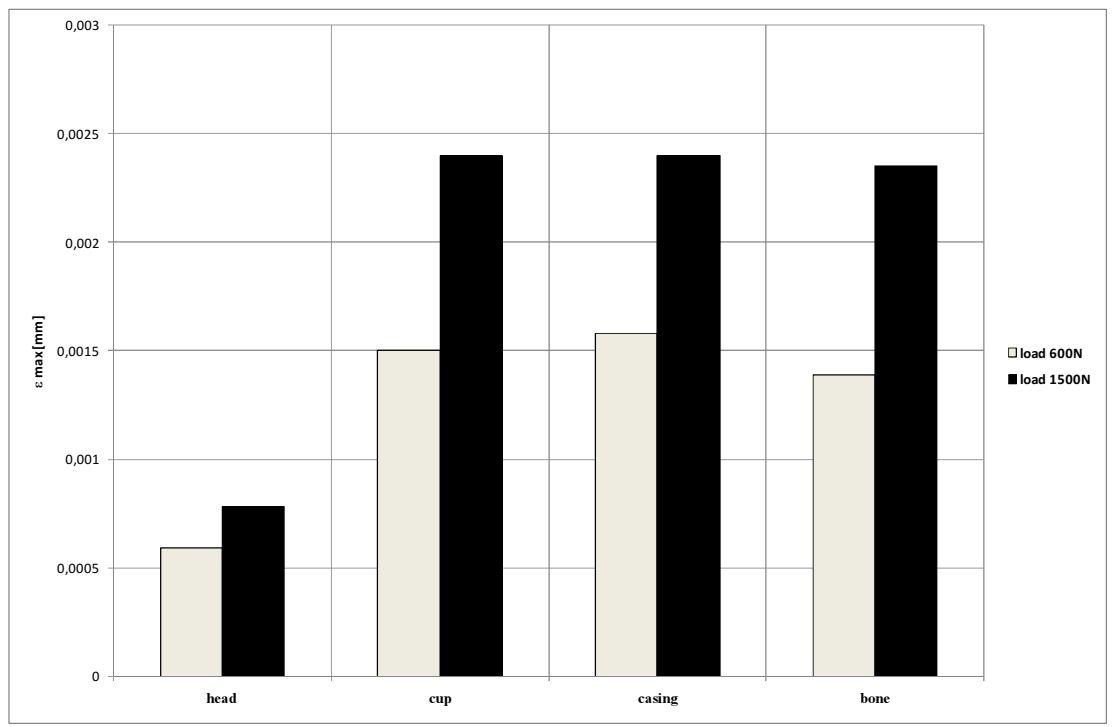

Fig. 10. Maximum values of the strain in the analyzed system "ceramic head - ceramic cup" with the loads 600 and $1500 \mathrm{~N}$

The analyzed stress pattern is proved to be concentrated inside the head of the endoprosthesis. Due to the contact between the surfaces of both elements the stress is transferred into the cup. Maximum stress value reached $2918 \mathrm{MPa}$ with the load $600 \mathrm{~N}$ and $3039 \mathrm{MPa}$ for the load $1500 \mathrm{~N}$. 
The stress is concentrated in the sub-surface layer of the head or directly in the area where the force is put to load the system.

The strain in the analyzed system "ceramic head - ceramic cup" is more concentrated in the deeper layers of the elements than in the area of their direct contact. They can even get to $0.0024 \mathrm{~mm}$ deep in case of titanium cup and cover.

For the pair "ceramic head - ceramic cup" there has been observed the higher strain where the cup is bounded to the cover and in the mechanic bone.

Such a concentration of stress and strain in case of tribological system can cause a danger of grinding and crushing or have a negative influence on friction conditions in the artificial joint.

\section{References}

[1] Kusz D., Biomechaniczne aspekty endoprotezoplastyk stawu biodrowego, Inżynieria Materiałowa 1998, 2(103), Rok XIX, marzec-kwiecień, 46-49.

[2] Oczoś K., Kształtowanie ceramicznych materiałów technicznych, Oficyna Wydawnicza Politechniki Rzeszowskiej, Rzeszów 1996.

[3] Mühlratzer A., Koberle H., Faserverstärkte Keramik für Anwendungen im Maschinenbau, Metall 1991, 45, 5, 434-440.

[4] The company brochure Aesculap nr 0-132.

[5] ADINA. Theory and Modeling Guide, Adina R\&D, INC. 1997.

[6] Będziński R., Biomechanika inżynierska, Oficyna Wydawnicza Politechniki Wrocławskiej, Wrocław 1997. 